\title{
Penerapan Teori Konstruktivisme untuk Meningkatkan Prestasi Belajar Materi Nilai Kebersamaan dalam Merumuskan Pancasila Pada Siswa Kelas IV SDN 4 Sumberagung
}

\author{
Eko Supriyadi ${ }^{1}$ \\ ${ }^{1}$ SDN 4 Sumberagung, Tulungagung \\ Email: ${ }^{1}$ ekosupriyadi@gmail.com
}

\begin{tabular}{l}
\hline Tersedia Online di \\
\hline http://www.jurnal.unublitar.ac.id/ \\
index.php/briliant \\
\hline \\
\hline Sejarah Artikel \\
Diterima pada Februari 2018 \\
Disetuji pada Februari 2018 \\
Dipublikasikan pada 13 Februari \\
2018 Hal. 101-112
\end{tabular}

\section{Kata Kunci:}

konstruktivisme, prestasi belajar, nilai kebersamaan, pancasila

\section{DOI:}

http://dx.doi.org/10.28926/briliant .v3i1.147

\begin{abstract}
Abstrak: Berdasarkan hasil observasi diketahui prestasi belajar siswa kurang memuaskan, yaitu dari 21 siswa hanya 7 siswa yang nilainya dapat mencapai $\mathrm{KKM}$ atau $\geq 70$, sedangkan 14 siswa lainnya masih belum dapat mencapai KKM atau $\leq$ 69. Untuk itu agar dapat meningkatkan prestasi belajar siswa dalam menyelesaikan soal tentang Nilai kebersamaan dalam proses perumusan Pancasila serta untuk tercapainya tujuan pembelajaran perlu diadakan perbaikan pembelajaran dengan menerapkan Teori Konstruktivisme. Penerapan pembelajaran Nilai kebersamaan dalam proses perumusan Pancasila melalui Teori Konstruktivisme dapat meningkatkan Prestasi belajar siswa Kelas VI SD Negeri 4 Sumberagung Tulungagung dan dapat mempermudah siswa dalam menyelesaikan persoalan Nilai kebersamaan dalam proses perumusan Pancasila.
\end{abstract}

Pendidikan kewarganegaraan dirumuskan secara luas untuk mencakup proses penyiapan generasi muda untuk mengambil peran dan tanggung jawab sebagai warganegara, dan secara khusus, peran pendidikan termasuk di dalamnya persekolahan, pengajaran dan belajar, dalam proses penyiapan warganegara tersebut. Pendidikan Kewarganegaraan adalah pendidikan yang menyangkut status formal warga negara yang pada awalnya diatur dalaam Undang-Undang No.2 tahun 1949 (Ruminiati, 2008: 25). Undang - Undang ini berisi tentang diri kewarganegaraan dan peraturan tentang naturalisasi atau pemerolehan status sebagai warga negara Indonesia (Winaputra, 1995; Ruminiati, 2008: 25).

Menurut Zamroni (Tim ICCE, 2005: 7) pengertian pendidikan kewarganegaraaan adalah Pendidikan demokrasi yang bertujuan untuk mempersiapkan warga masyarakat berpikir kritis dan bertindak demokratis, melalui aktivitas menanamkan kesadaran kepada generasi baru, bahwa demokrasi adalah bentuk kehidupan masyarakat yang paling menjamin hak-hak warga masyarakat". Diharapakan dapat mempersiapkan peserta didik menjadi warga negara yang memiliki komitmen yang kuat dan konsisten untuk mempertahankan Negara Kesatuan Rebuplik Indonesia. Hakekat NKRI adalah negara kebangsaan modern

Sedangkan tujuan umum pelajaran Pendidikan Kewarganegaraan ialah mendidik warga negara agara menjadi warga negara yang baik, yang dapat di lukiskan warga negara yang patiotik, toleran, setia terhadap bangsa dan negara, beragama, demokratis pancasila sejati (Soemantri, 2001:279). Sementara itu, 
Pendidikan Kewarganegaraan di Indonesia dapat diharapkan mempersiapkan peserta didik menjadi warga negara yang memiliki komitmen yang kuat dan konsisten untuk mempertahankan Negara Kesatuan Republik Indonesia. Hakikat negara kesatuan republik indonesia adalah negara kesatuan modern. Negara kebangsaan adalah negara yang pembentuknya didasarkan pada pembentukan semangat kebangsaan dan nasionalisme yaitu pada tekad suatu masyarakt untuk membangun masa depan bersama dibawah satu negara yang sama.walaupun warga masyarakaat itu berbeda-beda agama, ras, etnik, atau golongannya.

Pendidikan Kewarganegaraan di Indonesia dapat diharapkan mempersiapkan peserta didik menjadi warga negara yang memiliki komitmen yang kuat dan konsisten untuk mempertahankan Negara Kesatuan Republik Indonesia. Hakikat negara kesatuan republik indonesia adalah negara kesatuan modern. Negara kebangsaan adalah negara yang pembentuknya didasarkan pada pembentukan semangat kebangsaan dan nasionalisme yaitu pada tekad suatu masyarakt untuk membangun masa depan bersama dibawah satu negara yang sama.walaupun warga masyarakaat itu berbeda-beda agama, ras, etnik, atau golongannya.

Dalam proses pembelajaran di kelas sering timbul masalah yang pada umumnya dialami oleh siswa. Masalah yang dihadapi siswa bersifat unik berbeda satu sama lain. Misalnya masalah dan kesulitan ataupun rendahnya prestasi belajar yang dialami siswa pada mata pelajaran Pendidikan Kewarganegaraan bisa terjadi karena berbagai faktor diantaranya. Keterbatasan kemampuan, keadaan, minat dan motivasi diri siswa itu sendiri. Situasi belajar di sekolah atau kelas dan kurangnya sarana dan prasarana. Materi pelajaran yang kurang relevan dengan kebutuhan siswa Metode mengajar yang kurang bisa dipahami siswa bahkan kurangnya alat peraga dan alat bantu mengajar.

Apalagi mata pelajaran Pendidikan Kewarganegaraan menuntut kemampuan Guru untuk bisa membuat siswa mengerti dan memahami tentang materi yang diajarkan dengan tidak hanya membaca buku dan teori saja melainkan harus diterapkan dalam kehidupan sehari-hari, bermasyarakat dan berdaulat, agar siswa memiliki pengetahuan, keterampilan yang cerdas, terampil, berkarakter yang diamanatkan oleh Pancasila dan UUD 1945.

Berdasarkan hasil pengamatan dalam proses belajar mengajar dikelas, keadaan sekolah, dan melalui peninjauan bidang akademik dan non akademik, diperoleh hasil bahwa keadaan Sekolah Dasar Negeri 4 Sumberagung khususnya siswa kelas VI tahun ajaran 2015/2016 dalam pelajaran Pendidikan Kewarganegaraan belum menunjukkan prestasi belajar sesuai dengan KKM yang ditetapkan terutama pada nilai kebersamaan dalam proses perumusan Pancasila. Padahal, ditinjau dari keadaan fisik sekolah, yaitu ruang kelas VI sudah baik dan sesuai sebagai tempat berlangsungnya proses belajar mengajar. Pengamatan pada proses pembelajaran oleh peneliti dapat disimpulkan bahwa pelaksanaan proses belajar mengajar lah yang belum membuat siswa aktif belajar, sehingga kemampuan siswa belum tergali dengan maksimal.

Nasution (1996: 17) mengemukakan, prestasi belajar adalah kesempurnaan yang dicapai seseorang dalam berfikir, merasa dan berbuat. Pada ulangan harian Pendidikan Kewarganegaraan dengan nilai kebersamaan dalam proses perumusan Pancasila, di dapat rata-rata nilai sebesar 62,1 dari 21 siswa, padahal Kriteria Ketuntasan Minimalnya (KKM) telah ditentukan nilai sebesar 70. 
Dan hanya 7 siswa yang mendapat nilai di atas 70. Hal ini berarti, hanya 33,3\% dari siswa yang telah mencapai ketuntasan belajar, dan yang lainnya memiliki prestasi belajar yang rendah.

Oleh karena itu, demi memperbaiki berbagai masalah yang ada, peneliti memerlukan suatu solusi untuk mengatasi hambatan-hambatan yang terjadi. Akhirnya diputuskan dengan menggunakan Teori Konstruktivisme dalam pembelajaran Pendidikan Kewarganegaraan ini. Menurut faham konstruktivis pengetahuan merupakan konstruksi (bentukan) dari orang yang mengenal sesuatu (skemata). Pengetahuan tidak bisa ditransfer dari guru kepada orang lain, karena setiap orang mempunyai skema sendiri tentang apa yang diketahuinya. Pembentukan pengetahuan merupakan proses kognitif di mana terjadi proses asimilasi dan akomodasi untuk mencapai suatu keseimbangan sehingga terbentuk suatu skema (jamak: skemata) yang baru.

Teori Konstruktivisme adalah teori yang memberikan keaktifan terhadap siswa untuk belajar menemukan sendiri kompetensi, pengetahuan atau teknologi, dan hal lain yang diperlukan guna mengembangkan dirinya sendiri. Teori belajar tersebut berkenaan dengan kesiapan anak untuk belajar, yang dikemas dalam tahap perkembangan intelektual dari lahir hingga dewasa. Setiap tahap perkembangan intelektual yang dimaksud dilengkapi dengan ciri-ciri tertentu dalam mengkonstruksi ilmu pengetahuan. Misalnya, pada tahap sensori motor anak berpikir melalui gerakan atau perbuatan. Pembelajaran berdasarkan konstruktivisme memberikan kesempatan kepada siswa untuk mengungkapkan gagasan secara eksplisit dengan menggunakan bahasa siswa sendiri, berbagi gagasan dengan temannya, dan mendorong siswa memberikan penjelasan tentang gagasannya.

Sehingga tujuan dari penelitian ini adalah untuk mengetahui (1) bagaimana penerapan teori konstrukstivisme untuk meningkatkan prestasi belajar materi nilai kebersamaan dalam merumuskan pancasila pada siswa kelas IV SDN Sumberagung 4 Kabupaten Tulungagung, (2) apakah teori konstrukstivisme dapat meningkatkan prestasi belajar materi nilai kebersamaan dalam merumuskan pancasila pada siswa kelas IV SDN Sumberagung 4 Kabupaten Tulungagung

\section{METODE}

Penelitian tindakan sekolah ini dilaksanakan di ruang kelas VI Sekolah Dasar Negeri 4 Sumberagung Kecamatan Rejotangan Tulungagung. pada semester 1, pada tanggal 6 Agustus 2015 sampai dengan 13 Agustus 2015. waktu yang diperlukan 2 x 35 menit. Dalam penelitian ini subjek yang digunakan adalah seluruh siswa kelas VI Sekolah Dasar Negeri 4 Sumberagung Kecamatan Rejotangan Tulungagung tahun pelajaran 2015/2016 sebanyak 21 siswa yang terdiri dari 12 siswa putra dan 9 siswa putri.

Penelitian ini dilakukan dengan dua siklus, dimana masing-masing siklus dikenai perlakuan yang sejenis dengan bobot yang beda. Dibuat dua siklus dimaksudkan untuk memperbaiki system pengajaran yang dilaksanakan. 


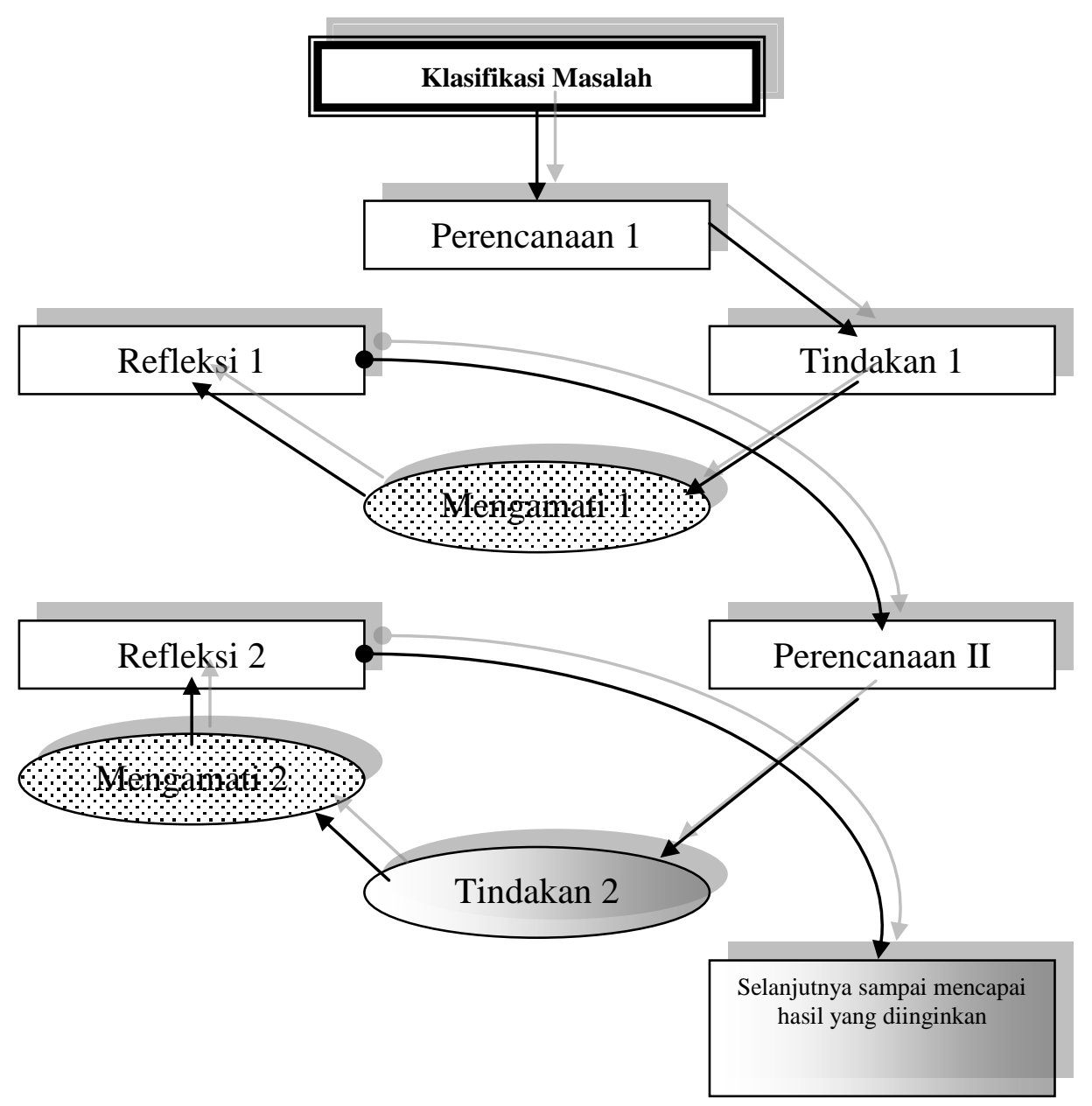

Gambar 1 Langkah-Langkah PTK dengan 2 Siklus

Adapun ragam instrument penelitian tindakan kelas yang telah dipersiapkan yaitu, Rencana Pelaksaaan Pembelajaran sebagai instrument rencana pelaksanaan tindakan. Lembar observasi Guru sebagai instrument utama pengumpul data proses dan lembar observasi siswa, wawancara, angket dan catatan lapangan sebagai instrument pendukung pengumpul data proses. Selain itu juga terdapat instrument pengumpul data hasil, yang dapat dikumpulkan dari hasil belajar berdasarkan soal-soal yang diberikan, serta ketrampilan siswa berdasarkan rubrik yang ada.

Teknik analisis yang digunakan yaitu deskriptif persentase. Data hasil penelitian yang dianalisis meliputi rata-rata kelas, ketuntasan belajar individu dan ketuntasan belajar secara klasikal. Selanjutnya hasil analisis data diperoleh baik secara kualitatif (dengan kata-kata) dan kuantitatif (dengan grafik). Hasil ini diinterprestasikan dan disimpulkan untuk menjawab permasalahan yang ada. Analisis data dari sumber-sumber informasi hasil penelitian di dapat dari: (1) Analisis dara observasi, Data hasil observasi keterlaksanaan pembelajaran melalui Teori Konstruktivisme dan observasi aktivitas siswa dianalisis secara deskriptif untuk memberikan gambaran pelaksanaan pembelajaran dengan menggunakan Teori Konstruktivisme. (2) analisis data wawancara, Hasil wawancara dengan siswa dianalisi secara deskriptif dengan lembar angket untuk mengetahui pendapat Guru dan siswa terhadap pembelajaran dan 3) analisis data tes. 


\section{HASIL}

\section{Siklus I}

\section{Observaasi Kegiatan Siswa}

Kegiatan observasi dilaksanakan saat proses pembelajaran Pendidikan Kewarganegaraan berlangsung. Kegiatan observasi difokuskan pada pelaksanaan pembelajaran. Dalam kegiatan ini, Guru mengamati jalannya pembelajaran. Pertama-tama Guru memberikan penjelasan, instruksi atau pertanyaan terhadap nilai kebersamaan dalam proses perumusan Pancasila dalam bentuk soal. Kedua, Guru mengamati langkah-langkah kegiatan siswa ketika melaksanakan percobaan, sudah sesuaikah langkah yang ditempuh siswa dengan langkah-langkah yang tertera dalam lembar kegiatan. Hasilnya, masih ada kelompok yang terlihat bingung dalam pelaksanaannya, ada yang kurang teliti, ada pula yang bingung dengan langkah yang harus dilaksanakan. Ketiga, Guru mengamati keaktifan siswa saat melaksanakan percobaan, ada beberapa siswa yang tidak aktif dalam melaksanakan percobaan, siswa tersebut hanya berdiam diri, seolah-olah tidak mau tahu.

Pengamatan selanjutnya, Guru mengamati bagaimana keaktifan siswa ketika berdiskusi untuk menarik simpulan, ada beberapa siswa yang aktif berargumen dan ada yang berdiam diri saja. Pengamatan yang paling akhir adalah bagaimana kesimpulan hasil diskusi siswa, apakah sesuai dengan hasil pelaksanaan percobaan atau tidak. Dari pengamatan yang terakhir ini ada tiga kelompok yang belum berani mempresentasikan hasil temuan, dan hanya terdapat 3 (tiga) siswa yang mau mengajukan pertanyaan. Hal ini disebabkan, kurangnya petujuk dan bimbingan dari Guru.

Dari uraian di atas dapat disimpulkan hasil observasi dari siklus I antara lain: Sebagian besar siswa mengerjakan tugas secara berkelompok dengan antusias. Sebagian besar siswa terlibat aktif dalam pembelajaran dengan menggunakan Teori Konstruktivisme. Sebagian besar siswa sudah memperhatikan penjelasan Guru. Hanya ada 5 siswa yang tidak memperhatikan, mereka justru mengajak bicara dengan teman sebangkunya. Sebagian besar siswa sudah dapat memahami lembar kegiatan dengan baik, hanya terdapat 5 siswa yang masih bertanya pada Guru tentang dasar hukum pelaksanaan kedaulatan yang dianut oleh Bangsa Indonesia. Baru terdapat sebagian kecil siswa yang ikut ambil bagian dalam diskusi kelompok. Sebagian besar siswa justru saling berbincang dengan teman duduknya. Terdapat 3 (tiga) kelompok yang melaksanakan diskusi dengan sungguh-sungguh. Dari 7 (tujuh) kelompok, baru terdapat 3 (tiga) kelompok yang sudah dapat menyelesaikan Lembar Kegiatan dengan tepat waktu. Sedangkan 4 (empat) kelompok yang lain membutuhkan waktu lebih dari 20 menit. Dari 7 (tujuh) kelompok, baru ada 3 (tiga) kelompok yang sudah berani mempresentasikan hasil temuan kelompoknya, sedangkan 4 (empat) kelompok yang lain belum berani.

Metode pembelajaran dengan memberikan tugas kepada peserta didik untuk menjabarkan pendapat tokoh tentang dasar Indonesia merdeka terlihat kurang efektif. Karena terlihat beberapa siswa masih banyak siswa yang belum memahami rumusan Pancasila dengan baik, sehingga waktu yang dialokasikan dalam pembelajaran kurang terlaksana dengan baik. Sewaktu presentasi hasil kelompok dilakukan, hanya terdapat 3 (tiga) siswa yang mau mengajukan pertanyaan. Sehingga dapat disimpulkan jika siswa kurang maksimal dalam 
menyerap konsep yang diajarkan. Masih ada beberapa siswa yang masih tampak binggung dalam melaksanakan kegiatan pembelajaran.

\section{Observasi Kegiatan Guru}

Melaksanakan pembelajaran sesuai dengan rencana pembelajaran yang telah disusun. Guru membuka pelajaran dengan baik, mengabsen siswa dan menyampaikan tujuan pembelajaran. Menjelaskan tentang pembelajaran dengan Teori Konstruktivisme. Karena masih baru di perkenalkan oleh siswa, beberapa siswa masih tampak binggung. Mengamati jalannya proses pembelajaran dan menilai kemampuan siswa dalam menyelesaikan tugas dalam kelompoknya. Aktif membimbing siswa. Selama diskusi berlangsung Guru berkeliling mengawasi, membimbing dan menjelaskan kepada siswa atau kelompok yang memerlukan penjelasan akan temuannya, agar hasil yang dicapai lebih optimal. Selain itu, Guru juga memotivasi siswa agar melakukan diskusi dengan baik. Guru menyuruh salah satu siswa untuk mempresentasikan hasil temuan kelompoknya dan memeriksa serta mengevaluasi dengan baik. Guru memotivasi siswa yang merasa malu untuk maju presentasi hasil temuan.

Adapun prosentase hasil observasi dalam pelaksanaan percobaan pada siklus I dapat dilihat dari tabel 3 bawah ini. Perhitungan prosentase keberhasilan siklus I di bawah ini diskusikan juga dengan teman sejawat.

Tabel 1 Prosentase Hasil Observasi Siklus I

\begin{tabular}{|c|l|c|}
\hline No & \multicolumn{1}{|c|}{ Kegiatan Siswa } & Prosentase \\
\hline 1 & Kelengkapan menyiapkan alat dan bahan percobaan & $33 \%$ \\
\hline 2 & Keruntutan langkah-langkah dalam pelaksanaan kegiatan percobaan & $40 \%$ \\
\hline 3 & Keaktifan siswa selama melaksanakan kegiatan percobaan & $66,7 \%$ \\
\hline 4 & Keaktifan siswa dalam mengutarakan pendapat saat berdiskusi & $55 \%$ \\
\hline 5 & Kesimpulan akhir sesuai percobaan & $48 \%$ \\
\hline
\end{tabular}

Hasil post test pada siklus pertama dapat menjadi perhitungan persentase peningkatan prestasi prestasi belajar siswa. Dengan acuan penilaian tetap berdasarkan nilai KKM yang telah ditetapkan yaitu paling sedikit siswa memperoleh nilai 70. Adapun rekapitulasi hasil test siklus I adalah sebagai berikut:

Tabel 2 Hasil Post Test Siklus Pertama

\begin{tabular}{|c|l|c|}
\hline No & \multicolumn{1}{|c|}{ Deskripsi } & Nilai \\
\hline 1 & Jumlah Nilai & 1525 \\
\hline 2 & Rata-rata Hasil Post Test & 72,6 \\
\hline 3 & Jumlah siswa yang mendapat nilai diatas KKM (70) & 14 \\
\hline 4 & Presentase siswa yang mendapat nilai diatas KKM (70) & $66,7 \%$ \\
\hline 5 & Jumlah siswa yang mendapat nilai dibawah KKM (70 & 7 \\
\hline 6 & Presentase siswa yang mendapat nilai dibawah KKM (70) & $33,3 \%$ \\
\hline
\end{tabular}

Nilai rata-rata hasil post test, dapat dihitung dari :

$\dot{X}=\frac{\sum X}{\sum N}$, Jadi $\dot{X}=\frac{1525}{21}=72,6$

Nilai $\mathrm{KKM}=70$. Jadi sudah ada peningkatan prestasi belajar, namun hanya sedikit. 
Rumus Ketuntasan Individu (prestasi belajar siswa) $=$ $\frac{\sum \text { siswa yang mendapat nilai } \geq 70}{\sum \text { siswa }} \times 100 \%$

Jadi, Ketuntasan Individu (prestasi belajar siswa) $=\frac{14}{21} \times 100 \%=66,7 \%$

Masing kurang dari indicator pencapaian siklus I sebesar $85 \%$ atau lebih. Maka dilanjutkan percobaan pembelajaran dengan Teori Konstruktivisme pada siklus II.

Tabel berikut adalah daftar frekuensi nilai post test siklus I Pendidikan Kewarganegaraan nilai kebersamaan dalam proses perumusan Pancasila dengan soal pengerjaan siswa kelas VI SD Negeri 4 Sumberagung Kecamatan Rejotangan Tulungagung setelah pembelajaran menggunakan Teori Konstruktivisme, dengan nilai minimal KKM sebesar 70:

Tabel 3 Daftar Nilai Ulangan Harian Siklus I

\begin{tabular}{|c|c|c|}
\hline Nilai & Frekuensi & Prosentase \\
\hline $0-40$ & 0 & $0.0 \%$ \\
\hline $41-69$ & 14 & $33,3 \%$ \\
\hline $70-100$ & 7 & $66,7 \%$ \\
\hline Jumlah & 21 & $100 \%$ \\
\hline
\end{tabular}

Dari tabel diatas dapat kita lihat terdapat 7 siswa atau 33,3\% yang mendapat nilai antara 41 - 69, dan 14 siswa atau 66,7\% yang mendapat nilai antara 70 - 100. Dengan ketentuan nilai KKM 70, dapat disimpulkan jika pencapaian prestasi nilai $70-100$, maka prestasi belajar siswa telah meningkat dari 35\% menjadi 66,7\%. Namun karena belum mencapai target indicator pencapaian siklus I sebesar $85 \%$ atau lebih, maka akan dilanjutkan ke Siklus II.

Selain itu, dari proses wawancara diperoleh kesimpulan bahwa beberapa siswa menjadi bersemangat dalam belajar Pendidikan Kewarganegaraan, karena pelaksanaan kegiatan belajar Pendidikan Kewarganegaraan dengan Teori Konstruktivisme ini dilaksanakan dengan langsung secara mandiri oleh siswa, dan melaksanakan kegiatan bersama kelompok sehingga lebih ringan. Meskipun masih terdapat kendala-kendala seperti yang telah diuraikan dalam laporan observasi.

\section{Siklus II}

\section{Observasi Kegiatan Siswa}

Pertama, dalam kegiatan ini, Guru mengamati jalannya pembelajaran. Kedua, Guru mengamati langkah-langkah kegiatan siswa ketika melaksanakan percobaan, sudah sesuaikah langkah yang ditempuh siswa dengan langkahlangkah yang tertera dalam lembar kegiatan. Pada siklus II ini Guru telah memberi bimbingan kepada kelompok-kelompok yang mengalami kesulitan pada siklus I untuk menerapkan langkah-langkah yang tertera dalam lembar kegiatan. Hasilnya, semua kelompok dapat memahami langkah-langkah pembelajaran dan dapat menjalankan kegiatan sesuai dengan lembar kegiatan yang tersedia. Ketiga, Guru mengamati keaktifan siswa saat melaksanakan percobaan, Pada siklus II ini kebanyakan siswa telah aktif dalam mengikuti pelaksanaan percobaan, hanya terdapat 3-4 siswa yang terlihat mengobrol ataupun berdiam diri. 
Pengamatan selanjutnya, Guru mengamati bagaimana keaktifan siswa ketika berdiskusi untuk menarik simpulan. Pengamatan yang paling akhir adalah bagaimana kesimpulan hasil diskusi siswa, apakah sesuai dengan hasil pelaksanaan percobaan atau tidak. Dari pengamatan yang terakhir ini, dengan adanya reward yang diberikan oleh Guru, semua kelompok berani mempresentasikan hasil temuannya, dan hanya terdapat 3-4 siswa saja yang kurang aktif dalam diskusi.

Dari uraian di atas dapat disimpulkan hasil observasi dari siklus II antara lain: Sebagian besar siswa mengerjakan tugas secara berkelompok dengan antusiasSebagian besar siswa terlibat aktif dalam pembelajaran dengan menggunakan Teori Konstruktivisme dengan cara siklus II. Hampir semua siswa sudah memperhatikan penjelasan Guru. Hanya ada 3-4 siswa yang tidak memperhatikan, mereka justru mengajak bicara dengan teman sebangkunya ataupun melamun. Dengan adanya reward, terdapat sebagian besar siswa yang ikut ambil bagian dalam diskusi kelompok. Sebagian kecil siswa masing tampak saling berbincang dengan teman duduknya ataupun melamun. Diskusi dilakukan dengan baik. 7 (tujuh) kelompok yang terbagi, mereka sudah dapat menyelesaikan Lembar Kegiatan dengan tepat waktu. Siswa yang terlihat lemah pada siklus I, lebih banyak mendapat perhatian dan bimbingan dari Guru. Dengan adanya reward, 7 (tujuh) kelompok sudah berani mempresentasikan hasil temuan kelompoknya. Mereka tampak detail dalam mempresentasikan hasil temuannya.

Metode pelaksanan pembelajaran Teori Konstruktivisme dengan membuat konsep presentasi proses perumusan Pancasila terlihat lebih efektif. Sewaktu presentasi hasil kelompok dilakukan, dengan adanya reward, hampir semua siswa mengajukan pertanyaan, hanya terdapat 3-4 siswa yang masih malu mengajukan pertanyaan. Sehingga dapat disimpulkan bahwa penerapan Teori Konstruktivisme siklus II ini maksimal dalam menyerap konsep yang diajarkan. Hasil post test menjukkan prestasi prestasi belajar siswa pun meningkat.

\section{Observasi Kegiatan Guru}

Pergantian pelaksanaan pembelajaran Teori Konstruktivisme dilaksanakan dengan baik. Melaksanakan pembelajaran sesuai dengan rencana pembelajaran yang telah disusun. Guru membuka pelajaran dengan baik, mengabsen siswa dan menyampaikan tujuan pembelajaran. Menjelaskan kembali tentang pembelajaran dengan Teori Konstruktivisme. Karena telah diperkenalkan sebelumnya, maka siswa telah memahami konsep dengan baik. Mengamati jalannya proses pembelajaran dan menilai kemampuan siswa dalam menyelesaikan tugas dalam kelompoknya. Aktif membimbing siswa. Selama diskusi berlangsung Guru berkeliling mengawasi, membimbing dan menjelaskan kepada siswa atau kelompok yang memerlukan penjelasan akan temuannya, agar hasil yang dicapai lebih optimal. Selain itu, Guru juga memotivasi siswa agar melakukan diskusi lebih baik lagi dan memberikan reward bagi mereka yang aktif. Guru menyuruh salah satu siswa untuk mempresentasikan hasil temuan kelompoknya dan memeriksa serta mengevaluasi dengan baik. Guru memotivasi siswa yang merasa malu untuk maju presentasi hasil temuan dan memberikan reward bagi mereka yang berani tampil presentasi. 
Adapun prosentase hasil observasi dalam pelaksanaan percobaan pada siklus II dapat dilihat dari tabel bawah ini. Perhitungan prosentase keberhasilan siklus II di bawah ini diskusikan juga dengan teman sejawat.

Tabel 4 Prosentase Hasil Observasi Siklus II

\begin{tabular}{|l|l|l|}
\hline No & Kegiatan Siswa & Prosentase \\
\hline 1 & Kelengkapan menyiapkan alat dan bahan percobaan & $70 \%$ \\
\hline 2 & $\begin{array}{l}\text { Keruntutan langkah-langkah dalam pelaksanaan kegiatan } \\
\text { percobaan }\end{array}$ & $85 \%$ \\
\hline 3 & Keaktifan siswa selama melaksanakan kegiatan percobaan & $87 \%$ \\
\hline 4 & Keaktifan siswa dalam mengutarakan pendapat saat berdiskusi & $85 \%$ \\
\hline 5 & Kesimpulan akhir sesuai percobaan & $82 \%$ \\
\hline
\end{tabular}

Hasil post test pada siklus kedua dapat menjadi perhitungan persentase peningkatan prestasi belajar siswa. Dengan acuan penilaian tetap berdasarkan nilai KKM yang telah ditetapkan yaitu paling sedikit siswa memperoleh nilai 70 . Adapun rekapitulasi hasil test siklus II adalah sebagai berikut:

Tabel 5 Hasil Post Test Siklus Kedua

\begin{tabular}{|l|l|l|}
\hline No & Deskripsi & Nilai \\
\hline 1 & Jumlah Nilai & 1760 \\
\hline 2 & Rata-rata Hasil Post Test & 83,8 \\
\hline 3 & Jumlah siswa yang mendapat nilai diatas KKM (70) & 19 \\
\hline 4 & Presentase siswa yang mendapat nilai diatas KKM (70) & $90,5 \%$ \\
\hline 5 & Jumlah siswa yang mendapat nilai dibawah KKM (70 & 2 \\
\hline 6 & Presentase siswa yang mendapat nilai dibawah KKM (70) & $9,5 \%$ \\
\hline
\end{tabular}

Nilai rata-rata hasil post test, dapat dihitung dari :

$\dot{X}=\frac{\sum X}{\sum N}$, Jadi $\dot{X}=\frac{1760}{21}=83,8$

Nilai $\mathrm{KKM}=70$. Jadi sudah ada peningkatan prestasi belajar yang signifikan.

Rumus Ketuntasan Individu (prestasi belajar siswa) =

$\frac{\sum \text { siswa yang mendapat nilai } \geq 70}{\sum \text { siswa }} \times 100 \%$

Jadi, Ketuntasan Individu (prestasi belajar siswa) $=\frac{19}{21} \times 100 \%=90,5 \%$

Telah mencapai indicator pencapaian siklus II sebesar $85 \%$ atau lebih.

Maka tidak perlu dilanjutkan percobaan pembelajaran dengan Teori

Konstruktivisme pada siklus III.

Tabel berikut adalah daftar frekuensi nilai post test siklus II Pendidikan Kewarganegaraan dengan nilai kebersamaan dalam proses perumusan Pancasila siswa kelas VI SD Negeri 4 Sumberagung Kecamatan Rejotangan Tulungagung setelah pembelajaran menggunakan Teori Konstruktivisme siklus II, dengan nilai minimal KKM sebesar 70:

Tabel 6 Daftar Nilai Ulangan Harian Siklus II

\begin{tabular}{|l|l|l|}
\hline Nilai & Frekuensi & Prosentase \\
\hline $0-40$ & 0 & $0.0 \%$ \\
\hline
\end{tabular}

109 BRILIANT: Jurnal Riset dan Konseptual Volume 3 Nomor 1, Februari 2018 


\begin{tabular}{|l|l|l|}
\hline $41-69$ & 2 & $9,5 \%$ \\
\hline $70-100$ & 19 & $90,5 \%$ \\
\hline Jumlah & 21 & $100 \%$ \\
\hline
\end{tabular}

Dari tabel diatas dapat kita lihat terdapat 2 siswa atau 9,5\% yang mendapat nilai antara $41-69$, dan 19 siswa atau $85 \%$ yang mendapat nilai antara 70 - 100. Dengan ketentuan nilai KKM 70, dapat disimpulkan jika pencapaian prestasi nilai 70 - 100, maka prestasi belajar siswa telah meningkat dari 66,7\% menjadi $90,5 \%$. Dengan $90,5 \%$ maka telah tercapai indicator pencapaian siklus II sebesar yang $85 \%$ atau lebih, maka tidak perlu dilanjutkan ke Siklus III.

Selain itu, dari proses wawancara diperoleh kesimpulan bahwa beberapa siswa menjadi bersemangat dalam belajar Pendidikan Kewarganegaraan, karena pelaksanaan kegiatan belajar Pendidikan Kewarganegaraan yang menggunakan Teori Konstruktivisme ini dilaksanakan dengan secara baik bersama kelompok menjadikan mereka lebih rileks dan ringan dalam mengerjakan laporan kegiatan. Meskipun masih terdapat kendala-kendala seperti yang telah diuraikan dalam laporan observasi.

\section{PEMBAHASAN}

Berdasarkan hasil pelaksanaan pada siklus I, II dapat dinyatakan bahwa terjadi peningkatan kualitas pembelajaran yang tampak dan perolehan hasil evaluasi dan keaktifan siswa. Dari tabel 4.2 dan gambar 4.2 siklus I hasil observasi menunjukkan, prosentase keberhasilan kelengkapan menyiapkan alat dan bahan percobaan $33 \%$, prosentase keruntutan langkah-langkah yang ditempuh dalam pelaksanaan percobaan $40 \%$, prosentase keaktifan siswa dalam melaksanakan kegiatan percobaan $66,7 \%$, prosentase keaktifan siswa dalam mengutarakan pendapat saat berdiskusi $55 \%$ dan prosentase hasil penarikan kesimpulan akhir sesuai percobaan $48 \%$.

Berdasarkan tabel 4.5 dan gambar 4.5 siklus II hasil observasi menunjukkan, prosentase keberhasilan metode kelengkapan menyiapkan alat dan bahan percobaan siswa yang disiapkan $70 \%$, prosentase keruntutan langkahlangkah yang ditempuh dalam pelaksanaan percobaan $85 \%$, prosentase keaktifan siswa dalam melaksanakan kegiatan percobaan $87 \%$, prosentase keaktifan siswa dalam mengutarakan pendapat saat berdiskusi $85 \%$ dan prosentase hasil penarikan kesimpulan akhir sesuai percobaan $82 \%$.

Dari daftar nilai (lihat lampiran) dapat kita lihat adanya prosentase kenaikan nilai Pendidikan Kewarganegaraan mulai dari kondisi awal pra tindakan, diketahui baru 7 siswa atau 33,3\% yang mengalami ketuntasan belajar dan mendapatkan nilai sesuai dengan KKM. Hasil evaluasi siklus I menunjukkan baru 14 siswa atau $66,7 \%$ yang mengalami ketuntasan belajar dan mendapat nilai sama dengan atau di atas KKM yaitu 70. Hal itu menunjukkan bahwa pelaksanaan siklus I belum mencapai keberhasilan, karena indicator pencapaian adalah sebesar $85 \%$ atau lebih. Siklus II menunjukkan ada 19 siswa atau 90,5\% dari 21 siswa yang mengalami ketuntasan belajar. Sehingga peneliti menyimpulkan bahwa pada siklus II ini peneliti telah mencapai keberhasilan dari penelitian tindakan kelas yang telah dilakukan.

Ketika peneliti melaksanakan siklus I, peneliti mengalami berbagai kendala antara lain siswa belum memahami rumusan Pancasila dengan baik. 
Masih ada kelompok yang bingung dalam mengikuti langkah-langkah yang tertera dalam lembar kegiatan. Masih ada beberapa siswa yang belum aktif dalam pelaksanaan percobaan. Ketika pelaksanaan diskusi, ada beberapa siswa yang tidak aktif menyampaikan pendapatnya. Dalam menyimpulkan hasil percobaan, terdapat 3 (tiga) kelompok yang malu untuk presentasi, dan hanya terdapat 3 (tiga) siswa yang mengajukan pertanyaan.

Peneliti kemudian melaksanakan siklus II sebagai perbaikan siklus I, sebelum pelaksanaan siklus II ini peneliti mengganti rencana pembelajaran Teori Konstruktivisme baru yaitu dengan membuat konsep presentasi proses perumusan Pancasila. Dalam pelaksanaan percobaan, peneliti senantiasa memberi bimbingan untuk siswanya dalam melaksanakan langkah-langkah sesuai lembar kegiatan. Peneliti pun memberi bimbingan siswa saat berdiskusi untuk menarik kesimpulan. Dengan adanya motivasi guru berupa reward, siswa telah terlihat aktif dalam kegiatan pembelajaran dalam melaksanakan percobaan, presentasi di depan kelas dan berdiskusi menarik kesimpulan. Meskipun ada kendala yaitu Siswa belum memahami cara konsep presentasi dengan baik, namun dengan hasil prestasi belajar yang dicapai dapat disimpulkan bahwa penelitian tindakan kelas dari siklus II ini telah berhasil.

\section{KESIMPULAN}

Berdasarkan hasil penelitian tindakan kelas yang telah dilaksanakan dalam 2 siklus dengan menerapkan Teori Konstruktivisme dalam pembelajaran Pendidikan Kewarganegaraan pada siswa kelas VI SD Negeri 4 Sumberagung Kecamatan Rejotangan Tulungagung, dapat dibuat kesimpulan sebagai berikut : Penerapan Teori Konstruktivisme dapat meningkatkan prestasi belajar Pendidikan Kewarganegaraan siswa kelas VI SD Negeri 4 Sumberagung Kecamatan Rejotangan Tulungagung. Adanya perubahan kenaikan prosentase dalam menyiapkan alat dan bahan, keruntutan langkah-langkah siswa dalam melaksanakan percobaan, keaktifan siswa dalam melaksanakan kegiatan percobaan, keaktifan siswa ketika berdiskusi dan hasil akhir atau simpulan.

\section{SARAN}

Berdasarkan hasil penelitian, maka ada beberapa saran yang dapat dipergunakan sebagai bahan pertimbangan dan sebagai bahan uraian penutup penelitian tindakan kelas ini, antara lain: (1) Bagi Guru, Guru juga harus memahami dan memvariasikan metode yang sesuai materi yang dapat digunakan dalam proses pembelajaran, sehingga siswa tidak merasa bosan. (2) Bagi Siswa, selalu mengerjakan tugas-tugas yang diberikan guru dan meningkatkan usaha belajar sehingga dapat memperoleh prestasi yang diharapkan. (3) Bagi Sekolah, Hendaknya mengupayakan pengadaan berbagai media pembelajaran Pendidikan Kewarganegaraan untuk kelas rendah, baik bantuan maupun swadaya sekolah, sehingga lebih menunjang dalam penanaman konsep-konsep Pendidikan Kewarganegaraan secara lebih nyata sekaligus meningkatkan aktivitas belajar siswa.

DAFTAR RUJUKAN

Ruminiati. 2008. Pengembangan Pendidikan Kewarganegaraan. Jakarta: Departemen Pendidikan Nasional 
Nasution. 1996. Azas-azas Mengajar. Bandung: Tarsito.

Soemantri, M. 2001 Menggagas Pembaharuan Pendidikan IPS, Bandung: Remaja Rosdakarya.

Tim ICCE. 2005. Pendidikan Kewargaan: Demokrasi, Hak Asasi Manusia dan Masyarakat Madani. Jakarta: Prenada Media.

Winataputra, US. 1995. Teori Belajar dan Pembelajaran. Bandung: Rosda Karya. 